https://doi.org/10.48009/1_iis_2009_198-207

\title{
EMPLOYERS AND EDUCATORS WANT INFORMATION SYSTEMS GRADUATES TO BE ABLE TO COMMUNICATE
}

\author{
Jeanne M. Baugh, Robert Morris University, baugh@ rmu.edu \\ Gary A. Davis, Robert Morris University, davis@rmu.edu \\ Paul J. Kovacs, Robert Morris University, kovacs@rmu.edu \\ John Scarpino, Robert Morris University, scarpino@ rmu.edu \\ David Wood, Robert Morris University, wood@ rmu.edu
}

\begin{abstract}
Computer and Information System students must be able to communicate effectively with their peers, supervisors, users and technical personnel. Attaining outstanding communication skills at the time of graduation can give the College graduate an edge up in the competition for employment. This paper documents what the employers are looking for in terms of communications skills in the entry lever CIS position. Also explored are various techniques that are being used in some institutions of higher Education to insure that communications skills are incorporated into all CIS courses.
\end{abstract}

Keywords: Communication Skills, Technical communication, CIS student communication skills

\section{INTRODUCTION}

All students graduating from College must be able to communicate. This includes the Computer Information Systems majors. They should be able to read, write, speak and comprehend in order to communicate technical issues to their peers, supervisors and end users. In fact, employers are increasing demanding this of their entry level employees [6] "Software programming skills are still in demand despite companies cutting back IT spending. But programmers must have strong communication skills if they are to secure work" [3].

Table 1 in the Appendix documents various IT job titles and communication requirements that are detailed in the IT job descriptions. This information was taken from the popular internet job site, "Monster.com" [9]. Although these are not entry level positions, they are an indication that communication skills are an

Volume X, No. 1 important element in many Information Technology positions. Many say that communication skills can be essential to a student's future success and at the very least, employers are looking for such skills [13]. But can an Information Systems professional be successful without good communication skills? In their research, Verbick and Tood state "While a solid technological base is desirable when hiring a computer lab consultant, communication and interpersonal skills are far more crucial than programming expertise" [12]. Although it may depend on the type of work being performed, often poor communication skills may cause major problems with the success of that work. For example, suppose a database designer is creating a database for a surgeon. It is very important that the designer communicate with the Physician in a manner that will enable him to understand exactly what data has to be stored and the relationships among the data. The Doctor does not understand the design process of a relational database and it is up to the database designer to ask the right questions and listen carefully to the Physician in order to facilitate a correct design.

"Current demands for graduates of Information Technology (IT) programs require that they possess deep technical skills, multidisciplinary awareness, and the ability to deliver the value of technical skills to customers and clients" [10]. It is no longer enough for the student to graduate with just the technical skills. One must be able to communicate the knowledge to others.

\section{ENTRY LEVEL IT JOB REQUIREMENTS}

What is the employer looking for in the entry level CIS position? How does the Computer Information Systems College graduate compete with others for that first job? Many have the same technical skills. Many

\footnotetext{
Issues in Information Systems
} 
have that high GPA. What is the "extra attribute" that the employer is looking for? Are they looking for something beyond just the technical skills?

The job site "Monster.com" is a popular recruitment tool for many employers. For this research, the website was searched, looking for jobs meeting the specific criteria: "computer related, entry level positions requiring a four year degree". One hundred job listings meeting the search criteria were analyzed for this study. The job descriptions for those 100 positions were researched to ascertain if communication skills were traits being looked for by the employers. Table 2 in the Appendix contains the job titles of these entry level positions. Within the job descriptions, various communication areas were described as being important to the employer. These were reading, writing, speaking, analysis of information and team interaction. Figure 1 summarizes the communication areas and the percentage of these job descriptions that required each particular skill set.

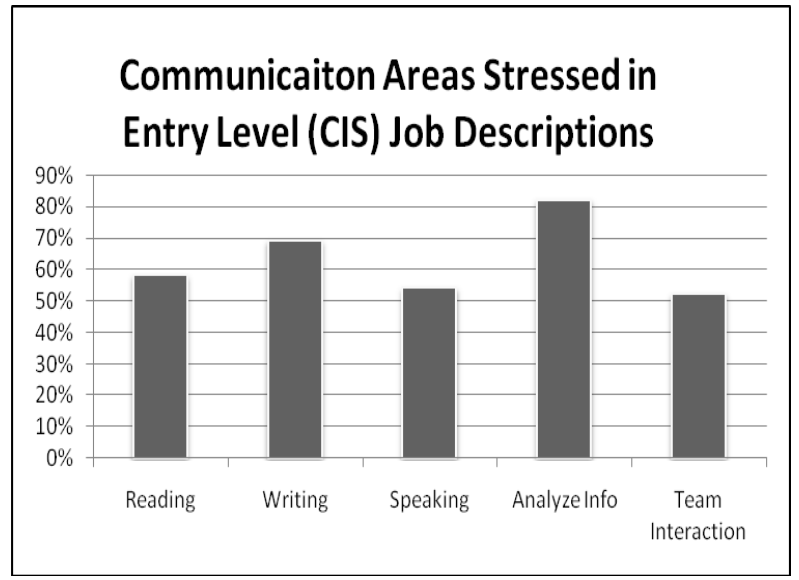

Figure 1. communication skills requirementsMonster.com

It makes sense that $82 \%$ of the entry level job descriptions require that the employee analyze information for technical positions. But it is also clear that soft skills such as reading, writing and speaking are highly valued.

Reading showed up in $58 \%$ of the jobs and writing appeared in $69 \%$. The area of reading and writing requirements included comprehention of technical documentation and project specifications along with ccurrency with industry publications. Examples of actual text from the job descriptions include; "Good oral and written communication skills essential", "Provide content for our technical writers and conduct internal training", and "Generation and analysis of access plans". Examples of speaking requirements (54\% indicaded) and team/interpersonal requirements (52\% indicaded) include "Communicate effectively with internal and external groups", "experience communicating with all levels of management", "Ability to communicate ideas in both technical and user-friendly language" and "Communicate technical issues with co-workers". Further analysis of the data indicated that $56 \%$ of the job descriptions had either the word communication or communicate within the text. Although this is just a snapshot of jobs that are posted at any given time, it is clear that the steroytype of the computer nerd working alone in a cubical has evolved to an employee with polished communication skills.

\section{COMMUNICATIONS SKILLS INCORPORATED IN TECHNICAL PROGRAMS}

Many people with talent, intelligence and ability don't achieve as well as expected. In many cases, lack of the right communications skills prevents others from realizing their value [1].

One University instituted a specific communications intensive project in a junior-level Advanced ObjectOriented Programming course. The communications effort was centered around a semester-long programming project with requirements well beyond just the programming code. This included various communication assignments related to the course work. That particular Institution was involved in a collegewide assessment program to both develop and evaluate the student's communication skills in disciplinespecific ways [8].

At the University of Alberta, Engineering students took part in an exercise in effective communications. The exercise involved sets of two students creating the exact same structure with legos by following specific verbal instructions. [14]. Students thought this was a 
perfect example of what may be lost by bad verbal communication.

Students at the City College in Thessaloniki, Greece hosted an interdisciplinary international student symposium with presentations of their work on a variety of subjects related to technology. Students having experience with scholarly presentations is something that is highly valued by the prospective employer [2].

At the Author's University in Pittsburgh Pennsylvania, communication skills are seen as an essential part of the student's educational experience. In fact, as part of the core, all University students are required to take four, 3 credit courses offered by the Communications Department. They also take four other, 3 credit courses from their own major that are defined as being communications intensive. All courses are semester long course work.

Because good communications skills is a concern during every semester and in every major, the students must be given the time necessary to develop proficiency in reading and interpreting, writing, speaking, listening, making presentations using appropriate software, developing skills in cross cultural and multicultural group dynamics, and applying rhetorical skills to each [4].

The Communications Skills Program (CSP) is a sequence of nine courses running through all four years of the student's instruction. Students are normally required to take eight of them: four in the University Core and four communications-intensive courses in their major field or closely related area of study. Short descriptions of the required University Core courses from the Communications Department are as follows:

\section{- COSK1221 (Argument and Research)} introduces students to academic reading, persuasive writing and the process of research. The Argument and Research course focuses on a rhetorical understanding of persuasive discourse.

- COSK2220 (Public Speaking and Persuasion) acknowledges the unity of the communications process of reading, listening, speaking, and writing. This course employs an integrated approach to communications in class discussion and assignments, with an emphasis on oral discourse and listening strategies.

- COSK2221

(Intercultural

Communications) reintroduces the integrated nature of the communications skills program and underscores the importance of communications for a successful life and career. While introducing small group process, COSK2221extends the study and practice of communications skills into multicultural and global contexts. Focusing on the complexity and diversity of group activity in the contemporary workplace, this course provides an understanding of and strategies for coping with groups comprised of persons having different ethnic, gender, racial, religious, organizational, and professional backgrounds and perspectives

- COSK2230 (Business and Professional Communications) assesses the degree to which students have succeeded in achieving the goals of the lower-division communications skills program. By reviewing and synthesizing the topics and skills covered in the previous four courses, by providing continued practice in all the communications skills, and by introducing the different communication practices of various disciplines and careers, COSK2230 emphasizes the integrated nature of the communications skills program and the importance of communications skills for a successful life and career.

Any course across the University can be designated as a communications intensive course. Adding the additional communication skills assignments to the course does not increase the number of credits. Not all CIS courses are offered in this format, but if the faulty member wishes to have his course designated as such a course, he must then meet the course requirements which are outlined through the Communications Department. A prescription of what must be done in any course to have it designated as communications

Issues in Information Systems 
intensive has been developed and the goals are as follows:

- A communications-intensive course includes specific communications skills outcomes in disciplinary contexts that require students to practice the CSP "strands" of reading, writing, listening, and presenting, as well as using appropriate technology.

A faculty member wishing to offer his course in this format may look to the Communications department for help. Many tools are in place to facilitate the successful teaching of such a course. Help is available in the areas of designing assignments, writing and administering exams and grading. The communication skills program also provides help to the students in the form of individual tutoring and writing labs.

\section{COMMUNICATION SKILLS PRACTICES AMONG CIS INSTRUCTORS}

Although various courses are offered in the communications intensive mode by the CIS department, many Instructors stress communications skills in all of their courses. In fact, when the Computer and Information Systems Department faculty at this Author's school were surveyed, $100 \%$ of the respondents stated that they construct communications type assignments and activities in courses that are not designated as communications intensive. Faculty agreed that it is essential in every course. In most cases, the CIS student will face daily interaction with others when on the job [1]. Because of this, every CIS course, no matter what the topic, can contain elements that enhance and build the student's communications skills.

The CIS faulty were surveyed to gain their views on the importance of communication skills, specifically in the CIS student. The faculty overwhelming agreed that all students should excel in the following tasks:

- Speak well in a large or small group

- Create and present a well organized power point presentation

- Write a formal research paper

- Write project documentation (pre/during/post)

Volume X, No. 1
- Write user manuals

- Write technical documentation

- Train and interact with users

- Work well in peer groups

- Read and comprehend reference manuals

- Read and comprehend industry articles/journals

Since the faculty feel that these skills are necessary for the CIS grad, they are constructing many assignments/activities in their classes that meet these requirements.

The following section contains examples of communication skills assignments that are given in various Computer Information System Courses:

\section{Communication Skills Assignments}

- $\quad$ Project Management One Instructor said, "I have the students make at least three presentations in class. They range from 10 to 20 minutes long. Students also must submit 24 written assignments, 21 of these assignments are done individually and are 310 pages long. The other three written assignments are done in teams, and these assignments focus upon the "Initiating" and "Planning" of an information systems project. Together, the three team assignments may end up being 40 to 60 pages long. As a class, the students also develop an electronic journal for the lecture materials, and it is shared by the students."

- Java Programming Students are required to produce a Technical Reference Guide as well as a User's Reference Guide accompanying a semester long large programming project.

- Training and Development in Business, As reported by the Instructor; "The students do various presentations. However, the final one has them teaching something (business subject or entertaining). They must do a lesson plan (with objectives, time frames, etc), use visual aids, have class participation, and test to see if their audience learned something. This usually Issues in Information Systems 
is 15 to 20 minutes long, depending on the number of students. The assignment uses all the communication skills."

- Data Warehousing Students write a research paper and then present that paper to the class centered on topics such as the theories and principles of data warehousing; the potential benefits of data warehousing; techniques and tools used to design a data warehouse; and the design of multi-dimensional data structures.

- Introduction to Information Systems (The following is a sample student assignment) You are to investigate software appropriate to your organization. You are to make recommendations as to what software package should be purchased to support the major function or functions of your organization. You will make a formal presentation to your boss (the class) summarizing your recommendation. This presentation is to be done using Power Point and should include all pertinent information in support of your recommendation.

- Database Management - Students create a database project for a real user. This requires the student to communicate with the user during all phases of the design and implementation process. Various design documents are produced and a formal presentation to the user is done at the end of the project

- $\quad$ Network Technology \& Mgt (N+) The student is to create a written report to solve a network scenario problem. In terms of the network design, the student is instructed to "Explain all the materials needed for its construction for your network design \& functionality. Network devices, OS, computer \& Network hardware specifications, wires, conduits, distance, location etc... Floor/ground plan diagrams need to be included. Every device and or material(s) being used needs to be explained and why it's implemented in your

Volume X, No. 1 project, its purpose, and usage?" Students also present their work to the class.

- Quality Issues of Information Technology Management In terms of identifying problems on various corporate web sites, the student is asked to create a report of their findings as if they were to present it to the organization's CIO.

- Ethical Issues in Computing The students are asked to review a video on information privacy and then construct an analysis of the ethical issues in the video. The student is to use a framework to analyze the ethical issues in the video and then write an analysis paper, taking and arguing a particular position.

- $\quad$ Still another Instructor said: "I typically have some sort of presentation in all of my classes. I usually have students work on group projects and then present their findings at the end." Table 3 in the Appendix is an example of a grading rubric that this particular Instructor uses for grading the student's presentation. It is clear by this rubric that communication skills are stressed, even in an Information Systems course.

\section{CONCLUSION}

We are living in a global society and being able to communicate is a must. For a computer professional to succeed they must be able to compete on a higher level than just the technical skills. Being able to communicate in all areas of reading, writing and speaking will give them an edge over others [7]. It is clear by this research that employers are putting communications skills at a premium. Every CIS course can contain assignments that reflect the goal of building and enhancing the communication abilities of the students. Good cooperation between the CIS and the Communications Departments can lead to unique and rewarding experiences for both the student and the Instructor [5]. Any CIS course can be turned into one

Issues in Information Systems 
that has an emphasis on communication skills without sacrificing the technical content of the course [11]. A CIS curriculum that prepares the student to communicate as well as attain the necessary technical skills, is one that should be highly valued.

\section{REFERENCES}

1. Dest (March 2002). Employability skills for the future. ACT, DEST. http://www.dest.gov.au/ty/publications/emplo yability_skills/final_report.pdf

2. Eleftherakis George, Konstantinos Dimopoulos, Anna Sotiriadou(2007) "Enhancing Student Communication Skills-the Case of the International Students Spring Symposium", Proceedings of the Informatics Education Europe II Conference IEEII 2007

3. Flinders, Karl(2009) http://www.computerweekly.com/Articles/2009/02 /12/234785/software-and-communication-skills-indemand.htm

4. Geisler, C.; Bazerman, C.; Doheny-Farina, S.; Gurak, L.; Haas, C.; Johnson-Eilola, J.; Kaufer, D.S.; Lundsford, A.; Miller, C.R.; Winsor, D. and Yates, J. (2001). IText: Future directions for research on the relationship between Information Technology and writing. Journal of Business and Technical Communication. 15(3): 269--308.

5. Granger Mary J. (2005)."Learning technical concepts with collaboration and communication skills" ACM SIGCSE Bulletin

6. Gruba Paul, Al-Mahmood Reem, (2004).

"Strategies for communication skills development", ACE '04: Proceedings of the sixth conference on Australasian computing education Volume 30

7. Henning, Henning, K. (2003). Writing 2003: Shifting boundaries and the implications for college teaching. TETYC. March. National Conference of Teachers of English. Online document: http://www.ncte.org/pdfs/subscribersonly/tetyc/0303-march03/TE0303Writing.pdf.

8. Michael, Mark (2000), "Fostering and assessing communication skills in the computer science context", ACM SIGCSE Bulletin archive Volume 32 , Issue 1 (March 2000)

9. Monster.com http://jobsearch.monster.com/Search.aspx?brd=1\& $\mathrm{re}=514 \& \mathrm{q}=\mathrm{it} \& \mathrm{cy}=\mathrm{us} \& \mathrm{lid}=316 \& \mathrm{re}=14 \# \mathrm{pg}=1 \& \mathrm{dv}=$ $1 \& l v=11 \& q=$ computer $\&$ indid $=77 \&$ cy $=$ us $\& l i d=31$ $6 \&$ re $=150 \&$ eid $=5$

10. Peterson Michael, Morneau Keith, Saad Ashraf (2003),"Preparing the new information technology professional in Virginia", Proceedings of the 4th conference on Information technology curriculum

11. Pollock, Lori, (2001) "Integrating an intensive experience with communication skills development into a computer science course", Technical Symposium on Computer Science Education Proceedings of the thirty-second SIGCSE technical symposium on Computer Science Education Charlotte, North Carolina, United States

12. Verbick Tabatha, Todd, Kim (2003), "Tech-NONerds: why the best student computer lab consultants are often not from the computer science department" Proceedings of the 31st annual ACM SIGUCCS conference on User services

13. Zachry Mark, Cargile Cook Kelli, Faber Brenton D., Clark David, (2001), SIGDOC '01:

Proceedings of the 19th annual international conference on Computer documentation

14. (www.engineering.ualberta 2009), http://www.engineering.ualberta.ca/ece/news.cfm? story $=88853$ 


\section{APPENDIX}

Table 1 Job Titles along with various Communication Skills requirements as taken from Monster.com

\begin{tabular}{|c|c|}
\hline Job Title & Communications Requirements \\
\hline Network Engineer/Field Technician & $\begin{array}{l}\text { must have excellent reading comprehension and } \\
\text { writing skills }\end{array}$ \\
\hline Installer & $\begin{array}{l}\text { Conducts pre-calls to clients, Documents } \\
\text { implementations }\end{array}$ \\
\hline Network Engineer & reporting on new communications technologies \\
\hline Lead Developer & Strong communication skills \\
\hline Project Engineer (Telecomm) & $\begin{array}{l}\text { Review contract packages, engineering quotes, } \\
\text { equipment lists, and prepare the necessary } \\
\text { documentation for the implementation process, } \\
\text { Provide professional consultation }\end{array}$ \\
\hline Networking Security Instructor & $\begin{array}{l}\text { create documentation, Thorough preparation of } \\
\text { both lecture and lab material }\end{array}$ \\
\hline Java Developer & Strong interpersonal and customer service skills \\
\hline Quality Assurance Engineer x 1 & $\begin{array}{l}\text { Must have strong organizational and } \\
\text { communication skills, and work well with cross- } \\
\text { functional teams }\end{array}$ \\
\hline Oracle Database Administrator x 1 & $\begin{array}{l}\text { team player and experienced working in a large } \\
\text { operational environment }\end{array}$ \\
\hline Software Programmer/Automation & Ability to do training, knowledge transfer \\
\hline Sr. Communications Analyst x 2 & Provide end user training \\
\hline Service Desk Analyst & $\begin{array}{l}\text { Analyst must have proven extraordinary customer } \\
\text { service skills, solid verbal and written } \\
\text { communication }\end{array}$ \\
\hline Data Analyst/ETL & $\begin{array}{l}\text { Document all ETL requirements, and source- } \\
\text { target mapping and reports as marts are released }\end{array}$ \\
\hline Data Translation Engineers & Auditing of existing documentation \\
\hline Security Engineer & $\begin{array}{l}\text { Author and maintain all requirement security } \\
\text { documentation }\end{array}$ \\
\hline
\end{tabular}

Table 2. Entry Level Job Titles

\begin{tabular}{|l|l|l|}
\hline $\begin{array}{l}\text { Application Solutions } \\
\text { Architect }\end{array}$ & IT administrator & Security Analyst \\
\hline $\begin{array}{l}\text { Application Support } \\
\text { Engineer }\end{array}$ & IT Developer & Software Application \\
Engineer I
\end{tabular}

Volume X, No. 1 


\begin{tabular}{|c|c|c|}
\hline $\begin{array}{l}\text { ASP.Net developer with } \\
\text { DOD Clearance }\end{array}$ & IT Support Technician & $\begin{array}{l}\text { Software Developer / } \\
\text { Software Engineer }\end{array}$ \\
\hline $\begin{array}{l}\text { Associate Developer - } \\
\text { Entry Level }\end{array}$ & $\begin{array}{l}\text { IT Web Application } \\
\text { Specialist }\end{array}$ & $\begin{array}{l}\text { Software Development } \\
\text { Engineer }\end{array}$ \\
\hline $\begin{array}{l}\text { Audit and Compliance } \\
\text { Analyst }\end{array}$ & Java Engineers & Software Engineer \\
\hline $\mathrm{C}++$ Developer & $\begin{array}{l}\text { Jr. Software Quality } \\
\text { Assurance Engineer }\end{array}$ & $\begin{array}{l}\text { Software Engineer for } \\
\text { Signal Processing }\end{array}$ \\
\hline Client Services Specialist & $\begin{array}{l}\text { Junior Configuration } \\
\text { Management Specialist }\end{array}$ & $\begin{array}{l}\text { Software QA Engineer } \\
\text { I }\end{array}$ \\
\hline Computer Engineer & $\begin{array}{l}\text { Junior Database } \\
\text { Administrator }\end{array}$ & $\begin{array}{l}\text { Software Quality } \\
\text { Assurance Engineer }\end{array}$ \\
\hline $\begin{array}{l}\text { Console Mechanical } \\
\text { TEST Engineer }\end{array}$ & $\begin{array}{l}\text { Junior Developer- } \\
\text { Object-Oriented }\end{array}$ & $\begin{array}{l}\text { Software Support } \\
\text { Engineer }\end{array}$ \\
\hline Data Analyst & Junior Programmer, IT & Support Analyst \\
\hline Database Administrator & $\begin{array}{l}\text { Junior Remedy } \\
\text { Consultant }\end{array}$ & Support Developer \\
\hline Database Architect & $\begin{array}{l}\text { Junior Software } \\
\text { Engineer }\end{array}$ & Support Specialist \\
\hline $\begin{array}{l}\text { Database Marketing } \\
\text { Analyst }\end{array}$ & $\begin{array}{l}\text { Junior Unix System } \\
\text { Administrator }\end{array}$ & System Administrator \\
\hline $\begin{array}{l}\text { Electronic Healthcare } \\
\text { Implementation Specialist }\end{array}$ & Junior Web Developer & Systems Analyst \\
\hline $\begin{array}{l}\text { Embedded Software } \\
\text { Engineer } 1\end{array}$ & $\begin{array}{l}\text { Learning Systems } \\
\text { Specialist }\end{array}$ & Systems Specialist \\
\hline Engineer, IT Operations & $\begin{array}{l}\text { Lotus Notes Software } \\
\text { Developer }\end{array}$ & Technical Analyst \\
\hline $\begin{array}{l}\text { Entry Level Computer } \\
\text { Programmer }\end{array}$ & Methodologist & Technical Engineer \\
\hline $\begin{array}{l}\text { Entry Level Computer } \\
\text { Programmer/Engineer }\end{array}$ & $\begin{array}{l}\text { NET Software } \\
\text { Developer }\end{array}$ & $\begin{array}{l}\text { Technical Support } \\
\text { Analyst }\end{array}$ \\
\hline $\begin{array}{l}\text { Entry Level Systems } \\
\text { Administrator (Helpdesk) }\end{array}$ & Net Web Developer & $\begin{array}{l}\text { Technical Support } \\
\text { Engineer }\end{array}$ \\
\hline $\begin{array}{l}\text { Entry Level Technical } \\
\text { Specialist }\end{array}$ & Network Analyst & Trading Programmer \\
\hline $\begin{array}{l}\text { Entry Level Technical } \\
\text { Consultants }\end{array}$ & Network Technician & $\begin{array}{l}\text { Unix Systems } \\
\text { Administrator }\end{array}$ \\
\hline Forms Developer & Operations Associate & VB.net developer \\
\hline $\begin{array}{l}\text { FPGA VHDL } \\
\text { Accelerated Computing } \\
\text { Engineer }\end{array}$ & $\begin{array}{l}\text { Photogrammetric } \\
\text { Systems Engineer }\end{array}$ & Web Design Analyst \\
\hline $\begin{array}{l}\text { Help Desk Support } \\
\text { Technician }\end{array}$ & $\begin{array}{l}\text { Problem } \\
\text { Solver/Technical } \\
\text { Engineer }\end{array}$ & Web Designer \\
\hline $\begin{array}{l}\text { HRO Set Up Config } \\
\text { Analyst }\end{array}$ & Programmer & Web Developer \\
\hline Info Assurance Engineer & Programmer Level I & $\begin{array}{l}\text { Web Developer } \\
\text { (Entry/Mid) }\end{array}$ \\
\hline $\begin{array}{l}\text { Information Assurance } \\
\text { Specialist }\end{array}$ & $\begin{array}{l}\text { SE-007 Software } \\
\text { Engineer }\end{array}$ & $\begin{array}{l}\text { Web Solicitation } \\
\text { Developer }\end{array}$ \\
\hline & & $\begin{array}{l}\text { Yahoo! Software } \\
\text { Engineer }\end{array}$ \\
\hline
\end{tabular}


Table 3 - Sample Rubric for Student Presentations Grading

\begin{tabular}{|c|c|c|c|c|c|}
\hline & 1 & 2 & 3 & 4 & Total \\
\hline Organization & $\begin{array}{l}\text { Audience cannot } \\
\text { understand } \\
\text { presentation } \\
\text { because there is no } \\
\text { sequence of } \\
\text { information. }\end{array}$ & $\begin{array}{l}\text { Audience has } \\
\text { difficulty following } \\
\text { presentation because } \\
\text { student jumps } \\
\text { around. }\end{array}$ & $\begin{array}{l}\text { Student presents } \\
\text { information in } \\
\text { logical sequence } \\
\text { which audience can } \\
\text { follow. }\end{array}$ & $\begin{array}{l}\text { Student presents } \\
\text { information in } \\
\text { logical, interesting } \\
\text { sequence which } \\
\text { audience can follow. }\end{array}$ & \\
\hline $\begin{array}{c}\text { Subject } \\
\text { Knowledge }\end{array}$ & $\begin{array}{l}\text { Student does not } \\
\text { have grasp of } \\
\text { information; } \\
\text { student cannot } \\
\text { answer questions } \\
\text { about subject. }\end{array}$ & $\begin{array}{l}\text { Student is } \\
\text { uncomfortable with } \\
\text { information and is } \\
\text { able to answer only } \\
\text { rudimentary } \\
\text { questions. }\end{array}$ & $\begin{array}{l}\text { Student is at ease } \\
\text { with expected } \\
\text { answers to all } \\
\text { questions, but fails } \\
\text { to elaborate. }\end{array}$ & $\begin{array}{l}\text { Student demonstrates } \\
\text { full knowledge } \\
\text { (more than required) } \\
\text { by answering all } \\
\text { class questions with } \\
\text { explanations and } \\
\text { elaboration. }\end{array}$ & \\
\hline $\begin{array}{l}\text { Visual Aids/ } \\
\text { Handouts }\end{array}$ & $\begin{array}{l}\text { Student uses } \\
\text { superfluous aids or } \\
\text { no aids }\end{array}$ & $\begin{array}{l}\text { Student occasionally } \\
\text { uses aids that rarely } \\
\text { support presentation. }\end{array}$ & $\begin{array}{l}\text { Student's aids } \\
\text { relate to } \\
\text { presentation. }\end{array}$ & $\begin{array}{l}\text { Student's aids } \\
\text { explain and reinforce } \\
\text { presentation. }\end{array}$ & \\
\hline Mechanics & $\begin{array}{l}\text { Student's } \\
\text { presentation has } \\
\text { four or more } \\
\text { spelling errors } \\
\text { and/or } \\
\text { grammatical } \\
\text { errors. }\end{array}$ & $\begin{array}{l}\text { Presentation has } \\
\text { three misspellings } \\
\text { and/or grammatical } \\
\text { errors. }\end{array}$ & $\begin{array}{l}\text { Presentation has no } \\
\text { more than two } \\
\text { misspellings and/or } \\
\text { grammatical errors. }\end{array}$ & $\begin{array}{l}\text { Presentation has no } \\
\text { misspellings or } \\
\text { grammatical errors. }\end{array}$ & \\
\hline Eye Contact & $\begin{array}{l}\text { Student reads all } \\
\text { of report with no } \\
\text { eye contact. }\end{array}$ & $\begin{array}{l}\text { Student occasionally } \\
\text { uses eye contact, but } \\
\text { still reads most of } \\
\text { report. }\end{array}$ & $\begin{array}{l}\text { Student maintains } \\
\text { eye contact most of } \\
\text { the time but } \\
\text { frequently returns } \\
\text { to notes. }\end{array}$ & $\begin{array}{l}\text { Student maintains } \\
\text { eye contact with } \\
\text { audience, seldom } \\
\text { returning to notes. }\end{array}$ & \\
\hline
\end{tabular}

Volume X, No. 1 


\begin{tabular}{|l|l|l|l|l|}
\hline \multirow{2}{*}{$\begin{array}{l}\text { Elocution } \\
\text { Student mumbles, } \\
\text { incorrectly } \\
\text { pronounces terms, } \\
\text { and speaks too } \\
\text { quietly for } \\
\text { students in the } \\
\text { back of class to } \\
\text { hear. }\end{array}$} & $\begin{array}{l}\text { Student's voice is } \\
\text { low. Student } \\
\text { incorrectly } \\
\text { pronounces terms. } \\
\text { Audience members } \\
\text { have difficulty } \\
\text { hearing presentation. }\end{array}$ & $\begin{array}{l}\text { Student's voice is } \\
\text { clear. Student } \\
\text { pronounces most } \\
\text { words correctly. } \\
\text { Most audience } \\
\text { members can hear } \\
\text { presentation. }\end{array}$ & $\begin{array}{l}\text { Student uses a clear } \\
\text { voice and correct, } \\
\text { precise } \\
\text { pronunciation of } \\
\text { terms so that all } \\
\text { audience members } \\
\text { can hear } \\
\text { presentation. }\end{array}$ \\
\hline & & & & Total Points: \\
\hline
\end{tabular}

